Bulletin of Department of Geology, Tribhuvan University, Kathmandu, Nepal, vol. 22, 2020, pp. 17-23.

DOI: https://doi.org/10.3126/bdg.v22i0.33410

\title{
Local level Disaster Response in Nepal: Investigating the Govern- ment Agencies
}

\author{
Shrijan Bahadur Malla ${ }^{*}$, Ranjan Kumar Dahal ${ }^{2}$ and Shuichi Hasegawa ${ }^{3}$ \\ 1. Faculty of Engineering, Graduate School of Engineering, Kagawa University, Japan \\ 2. Central Department of Geology, Tribhuvan University, Kritipur, Nepal \\ 3. Department of Safety Systems Construction Engineering, Kagawa University, Japan
}

\begin{abstract}
Effect local level disaster response is always questionable in Nepal. It is because the capacity of local responding bodies' i.e. local administration, elected representatives and security forces is deficit. Overlooking own role and responsibility by public service offices such as health, water supply, road network, rural development, communication, education has overburdened the responsibility of CDO during disaster response and eroded the effectiveness of cluster approach. Similarly, over-reliance on security forces from relief and rescue to rehabilitation and reconstruction have also garnered lethargy amongst civil administration and public service offices wearing away their capacity. For that reason, it is utmost important that the prevailing tendency should be altered and derailed local level response mechanism should be brought into the right track.
\end{abstract}

Key words: Disaster, reconstruction, local-level

Received: 16 February 2020

Accepted: 12 October 2020

\section{INTRODUCTION}

Nepal is amongst the 20th most disaster-prone countries in the world (MoHA, 2018). The country is at 4th position in terms of climate change threat and 11th position in terms of earthquake threat (MoHA, 2018). Today more than $80 \%$ of the total population is living under the vulnerability of natural disasters like landslide, earthquake, flood, fire, cold wave, avalanche, inundation and glacial lake outburst (MoHA and DPNET, 2015; MoHA 2017). Every year around 400 people are dying in Nepal due to such catastrophes (MoHA, 2018) (Table 1).

Besides this reality effective disaster response has always remained an arduous responsibility for the country (Lee, 2016; Piper, 2013; Sanderson and Ramalingam, 2015). Key behaviors like coordination during the response, damage assessment, information management, search and Rescue, and relief material management, etc have always been tricky jobs during response operations (Sanderson and Ramalingam, 2015; MoHA, 2017). Koshi flood of 2008, Jure landslide of 2014, Gorkha Table of 1. Human deaths from major disasters since 2000 to 2018 earthquake of 2015 and Bara-Parsa tornado 2019 are some notable examples of disasters where such complexities overwhelmed (Nepal et al., 2018; Khanal and Gurung, 2014; MoHA and DPNET, 2015).

\footnotetext{
*Corresponding author

Email: shrijan7malla@hotmail.com
}

Table 1. Human deaths from major disasters since 2000 to 2018

\begin{tabular}{|c|c|c|c|c|c|c|c|c|c|}
\hline$\stackrel{\grave{\Xi}}{\grave{\nu}}$ & 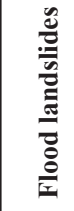 & 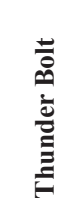 & 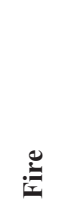 & 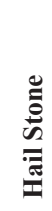 & 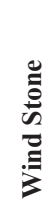 & 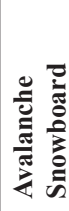 & 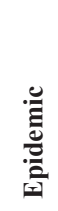 & 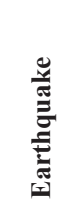 & हूँ \\
\hline 2000 & 173 & 26 & 37 & 1 & 2 & - & 141 & 0 & 380 \\
\hline 2001 & 196 & 38 & 26 & 1 & 1 & - & 154 & 1 & 417 \\
\hline 2002 & 441 & 6 & 11 & 0 & 3 & - & 0 & 0 & 461 \\
\hline 2003 & 232 & 62 & 16 & 0 & 20 & - & 0 & 0 & 330 \\
\hline 2004 & 131 & 10 & 10 & 0 & 0 & - & 0 & 0 & 151 \\
\hline 2005 & 141 & 18 & 28 & 0 & 0 & 21 & 41 & 0 & 249 \\
\hline 2006 & 141 & 15 & 3 & 1 & 0 & - & 34 & 0 & 194 \\
\hline 2007 & 216 & 40 & 9 & 18 & 1 & 6 & 0 & 0 & 290 \\
\hline 2008 & 134 & 16 & 11 & 0 & 2 & 0 & 3 & 0 & 166 \\
\hline 2009 & 135 & 7 & 35 & 0 & 0 & 2 & 10 & 0 & 189 \\
\hline 2010 & 240 & 70 & 69 & 0 & 2 & 2 & 462 & 0 & 845 \\
\hline 2011 & 263 & 95 & 46 & 2 & 6 & 0 & 36 & 0 & 448 \\
\hline 2012 & 123 & 119 & 77 & 0 & 18 & 9 & 9 & 6 & 361 \\
\hline 2013 & 219 & 146 & 59 & 0 & 3 & 7 & 4 & 0 & 438 \\
\hline 2014 & 241 & 96 & 62 & 0 & 3 & 38 & 12 & 0 & 452 \\
\hline 2015 & 293 & 115 & 53 & 0 & 2 & 2 & 18 & 9366 & 9849 \\
\hline 2016 & 297 & 105 & 85 & 0 & 4 & 0 & 14 & 0 & 505 \\
\hline 2017 & 236 & 85 & 63 & 0 & 5 & 1 & 10 & 0 & 400 \\
\hline 2018 & 105 & 68 & 89 & 0 & 45 & 19 & 0 & 0 & 326 \\
\hline Total & 3957 & 1137 & 789 & 23 & 117 & 107 & 948 & 9373 & 16451 \\
\hline
\end{tabular}


Legally, a year earlier promulgated Disaster Risk Reduction and Management Act 2017 (DRRMA) has given newer dynamic to the venture which remained reactive for decades. Besides, the National Disaster Response Framework 2018 (NDRF) and Local Government Operation Act, 2017(LGOA) are the supplementary legal framework to assist the endeavor (Nepal et al., 2018). These legal frameworks have entrusted the Ministry of Home Affairs (MoHA) as focal ministry whereas delegated other ministries such as Federal Affairs and General Administration, Urban Development, Agriculture, Water Supply, Health, Education and so on equal responsibility. Precisely for a response, four tiers of mechanisms have been designed in the country i.e. central, provincial, district and local (Nepal et al., 2018). But practically since district and local levels have been functioning concurrently joining shoulder to shoulder can be called as a local level.

Indeed, local-level disaster response mechanism is the most accountable tier for response since it remains close to the public providing direct assistance (Kharel, 2018; MacManus and Caruson, 2006; Kpaucu and Van wart, 2006). This mechanism comprises of local administration (includes CDO office and public service offices like health, education, water supply, communication, road network, agriculture, urban development etc), elected representative (mayors, deputy mayors, ward chief and ward members etc) and, security forces (Nepali Army, Nepal Police and Armed Police Force). And it is imperative that these local bodies should be knowledgeable and well prepared for effective disaster response. Niekerk (2007) stressed that in the void of competent local bodies disaster response will always remain less effective that leads to the lethargic recovery of disaster victims that ultimately pushes the society into the dire depression of poverty and underdevelopment.

As per the framework, District Disaster Management Committee (DDMC) and Local Disaster Management Committee (LDMC) are two mechanisms active at the local level to render effective response (Disaster Risk Reduction and Mitigation Act, 2017) (see Figure 1). DDMC remains at the district level which is moreover a coordinating entity focuses on response operations whereas LDMC remains at

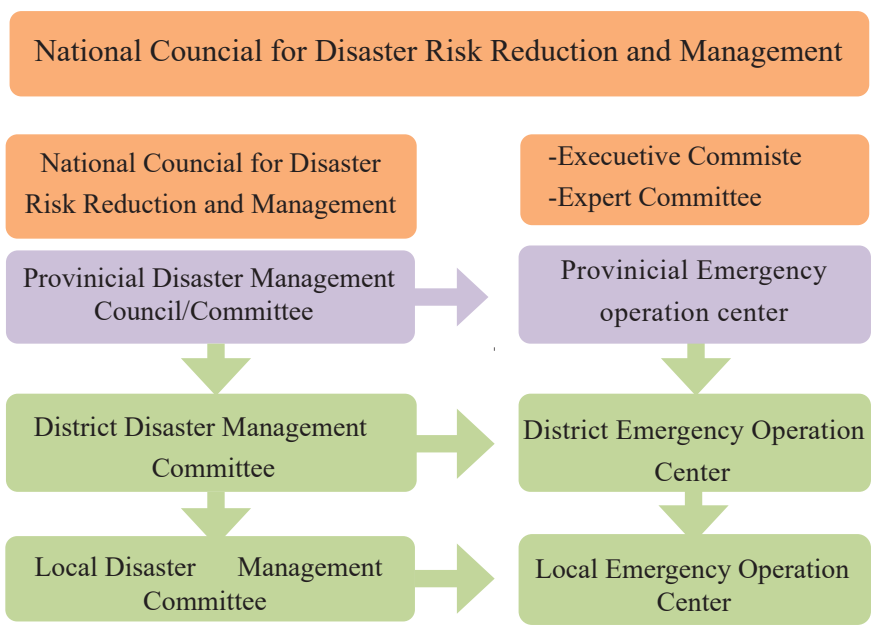

Fig.1: National Disaster Management Structure municipality level that focuses on mitigating disaster risk, resilient building, and disaster response functions. DDMC is chaired by Chief District Officer (CDO) whereas LDMC is chaired by the mayor of the respective municipality (Disaster Risk Reduction and Management Act, 2017).

Besides, the District Emergency Operations Center (DEOC), led by CDO's office, is another body to takes overall command of response operations at the district level (MoHA, 2017).

Indeed, disaster response is not an easy process, especially for poor countries like Nepal, where lack of resources, lack of coordination, duplication of effort, lack of clear leadership and accountability are always the steadfast problems. In 2005, to get rid of these problems the United Nation's Humanitarian Reform Agenda introduced a tool known as 'cluster approach' (IASC, 2006).

The national framework has envisioned nine clusters to function at the local level (MoHA, 2013) (see Table 2). And DEOC is responsible to mobilize these clusters at the time of crisis in which public service offices, local government bodies, non-governmental humanitarian agencies, security forces, and concerned public agencies are the equal partners (IASC, 2006; MoHA, 2013).

Table 2. Clusters at National and Local Levels

\begin{tabular}{|c|c|c|c|c|}
\hline \multirow{2}{*}{$\begin{array}{l}\text { S. } \\
\text { No }\end{array}$} & \multirow[t]{2}{*}{ Name of clusters } & \multicolumn{2}{|c|}{ Government Lead Agency } & \multirow[t]{2}{*}{ Assisting agency } \\
\hline & & NationalLevel & Local Level & \\
\hline 1 & Health & $\begin{array}{l}\text { Ministry of Health and } \\
\text { Population }\end{array}$ & Office of District Health & WHO \\
\hline 2 & WASH & $\begin{array}{l}\text { Ministry of Water Supply and } \\
\text { Sewage }\end{array}$ & $\begin{array}{l}\text { Water Supply and Sanitation } \\
\text { Division Office }\end{array}$ & UNICEF \\
\hline 3 & Emergency Shelter & $\begin{array}{l}\text { Ministry of Urban } \\
\text { Development }\end{array}$ & $\begin{array}{l}\text { Urban Development and } \\
\text { Building Construction } \\
\text { Division Office }\end{array}$ & $\begin{array}{l}\text { IFRC/UN } \\
\text { HABITAT }\end{array}$ \\
\hline 4 & Food Security & $\begin{array}{l}\text { Ministry of Agriculture and } \\
\text { Livestock Development }\end{array}$ & $\begin{array}{l}\text { District Agriculture } \\
\text { Development Office }\end{array}$ & WFP/FAO \\
\hline 5 & Nutrition & $\begin{array}{l}\text { Ministry of Health and } \\
\text { Population }\end{array}$ & Office of District Health & UNICEF \\
\hline 6 & $\begin{array}{l}\text { Camp Coordination } \\
\text { and Camp } \\
\text { management }\end{array}$ & $\begin{array}{l}\text { Ministry of Rural } \\
\text { Development }\end{array}$ & (n) & IOM \\
\hline 7 & Protection & $\begin{array}{l}\text { Ministry of Women, Children } \\
\text { and Senior Citizen }\end{array}$ & $\begin{array}{l}\text { District Office of Women } \\
\text { and Children }\end{array}$ & $\begin{array}{l}\text { UNHCR/UNICE } \\
\text { F/UNFPA }\end{array}$ \\
\hline 8 & Early Recovery & $\begin{array}{l}\text { Ministry of Federal Affairs and } \\
\text { General Administration }\end{array}$ & 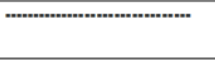 & UNDP \\
\hline 9 & Education & $\begin{array}{l}\text { Ministry of Education, Science } \\
\text { and Technology }\end{array}$ & District Education Office & UNICEF/SC \\
\hline 10 & Logistics & Ministry of Home Affairs & CDO'sOffice & WFP \\
\hline 11 & $\begin{array}{l}\text { Emergency } \\
\text { Communication }\end{array}$ & $\begin{array}{l}\text { Ministry of Communication } \\
\text { and Information Technology }\end{array}$ & CDO'sOffice & WFP \\
\hline 12 & Search and Rescue & 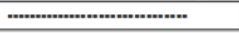 & CDO'sOffice & \\
\hline
\end{tabular}

Unfortunately, besides these developments, still, the country's disaster management endeavor relies on response operations. Pre-disaster ventures like risk reduction and mitigation through development work, building the resilient capacity of the society and even robust preparedness for the response have remained in shadow. The tendency of over-reliance on security forces, especially Nepali Army and non-government humanitarian agencies are at large. When disaster occurs, in the leadership of $\mathrm{CDO}$, the security forces are heavily engaged for search and rescue, relief and rehabilitation. Similarly, relief material management is expected from NGO/INGOs. Private and public sector assistance goes beyond the control of the local 
Local level Disaster Response in Nepal: Investigating the Government Agencies.

authority. This sort of behavior is not only making civilian components lethargic but also weakening the overall cluster approach in a larger context. In that sense how to make such local bodies accountable and how to ensure their active involvement in response operation is always a challenge for the state.

In this backdrop it is an utmost important that the organs of local-level response mechanism i.e. ' civil administration' and 'local elected representative', and the security forces - 'the Nepali Army, Nepal Police, and Armed Police Force' should remain competent at their roles and responsibilities of disaster response (see figure 2). But hardly this matter has been studied earlier in Nepal. In this context, this paper aims to investigate the competency of these institutions in local level disaster response.

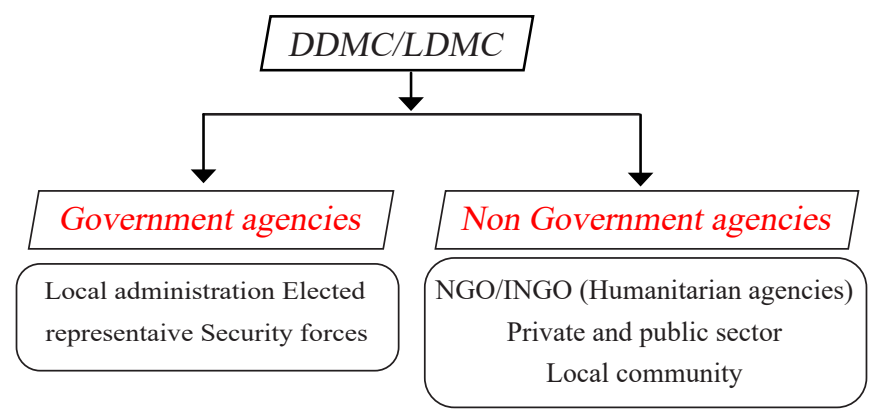

Fig. 2: Companents of local Level disaster response mechanism

\section{METHODOLOGY}

This paper is qualitative research, a combination of both a qualitative interview and literature review. Both the procedures mainly focused on to investigate the competency of local-level disaster response mechanism of Nepal. At first qualitative interviews were carried out with the various individuals working in disaster management venture. Interviewees were selected considering two aspects: at first, he or she should be familiar with the national mechanism including national policy, legal framework and structural framework and secondly, he or she should be acquainted with the local level response mechanism, its structure, and prevailing challenges. Ministerial officials, multilateral organizations' members such as Nepal Red Cross Society, DPNet-Nepal (Disaster Preparedness Network - Nepal) and UNWFP (United Nations World Food Programme), national security forces disaster expert i.e. Nepali Army, Armed Police Force and Nepal Police, their field officers, district administrative official and local elected representatives configured the interviewees group. This paper is also informed by informal conversations with related individuals of different capacity.

Fundamentally, during interview questions were asked about the existing national and local level mechanism, various organizational involvement, their structural framework, preparedness mechanism, and prevailing challenges in due process of response that ranges from national to the local level. Especially security forces' experts were asked about their organizational structure, capacity building endeavors and involvement constrains.

Similarly, the study of disaster management literature, legal documents, policy documents, binding, and nonbinding national and international guidelines and Nepali grey literature was also part of this research. Earlier disaster reports were also studied to investigate the gaps and challenges faced by the time of responses.

Ultimately the entire research was focused onto carrying out two analyses. The first analysis addresses the national and institutional disaster response framework and mechanism, whereas the second analysis focuses on the local level mechanism and prevailing challenges during response operations. In part of the second analysis further assessment is done to understand the existing gaps in local level disaster response competency.

\section{ANALYSIS}

\section{Civil Administration and Elected Representative}

In today's context, disaster management is an indispensable task of every state's authority. Comprehending this need the Nepalese government has also incorporated disaster management as the integral parts of every agencies and services (Chettri, 1999). The Nepal's Constitution 2015, Disaster Risk Reduction and Mitigation Act 2017, Disaster Risk Reduction National Policy 2018, Disaster Risk Reduction National Strategic Action Plan 2018-2030, Local Government Operation Act 2017, National Strategy for Disaster Risk Management in Nepal 2009, National Building Code 1993 and National Disaster Response Framework are the legal binding guidelines to enact such provisions mandatory for the state's organs.

Amongst three tiers of state mechanism-center, province and local- local administration i.e. district and local government is the most responsible entity to work for disaster response venture (Disaster Risk Reduction and Mitigation Act, 2017; Local Government Operation Act, 2017). Since they remain in direct contact to the public and by virtue of their sheer mandate disaster response is their solo responsibility (Kharel, 2018; MacManus and Caruson, 2006). Province and center governments are to assist local level mechanism at the needy time. In that sense, as representing the government, the officials working in civil administration and public services at local level such as health, water supply, road network, education, agriculture, electricity, communication etc and the local elected representative such as mayors, deputy mayors, ward chief, and ward members who are the member of local governments, should be well knowledgeable and prepared to assist local people at the time of disaster.

Precisely for effective response cluster approach is an efficient mechanism designed by the National Response Framework. 
During disaster altogether nine clusters should be activated at the local level. And district and local level officials of the respective ministries should lead the respective clusters. But this practice has hardly been materialized in Nepal. A disaster expert once noted that "CDO office only takes the pain of entire response and relief operations during a disaster. Other officials hardly get bothered about their responsibility". He added that "it is because there is no effective command control mechanism at the local level and no effective system to check and balance their work especially in disaster response".

"Earlier there was no act so legal mandate was weak. But now the Disaster Risk Reduction and Mitigation Act 2017 is already in place. So every responsible body should pull up their shocks. There is no room for an excuse" described by the head of the response operation of Nepal Red Cross Society. Even to some extent, the government has also overlooked this venture. The Ministry of Home Affairs, the apex body, has amalgamated 'conflict resolution' and 'disaster management' in one place and has named 'the Disaster and Conflict Management Division' to the respective department (Dawadi, 2019). Expert says that conflict and disaster are two different dynamics. During conflict resolution, a state can be biased but during the disaster, management state shouldn't be biased (UNDP, 2011). Such a lethargic tendency has been transmitted up to the local level.

Similarly, during the recent tornado at Bara and Parsa the engagement of local elected representatives in response and relief operations were found negligible (Malla et.al., 2019). Similar dearth was observed during recent flooding at Rautahat, Sarlahi, Dhanusha, and Siraha. "There is lack of awareness in elected representatives" once replied by the ex-chairman of DPNET, an NGO working for disaster risk reduction in Nepal. "The lack of capacity building initiatives is the main crux of the problem. Besides the heavy reliance on security forces is another drawback of the system" he further added.

Indeed security forces are the indispensable tool for disaster response for a poor country like Nepal. It is because the country can't afford another civil mechanism for the purpose. But over-relying on security forces from search and rescue to relief distribution, rehabilitation, and reconstruction is also not logical as well. It will ultimately weaken the civil mechanism. That will ultimately bring a sense of lethargy and irresponsiveness amongst local administrative officials and elected representatives at the local level.

\section{The Nepali Army}

Like other militaries in the world, the Nepali Army is also an indispensable disaster response tool of the Nepalese government. Her specific human and logistic resources, capacity to respond quickly on a larger scale and national political imperative have made this organization reliable tool for disaster response (Manandhar et al., 2017; Thapa, 2016; Marshall and Adkin, 2016; The Constitution of Nepal, 2015; Disaster Risk Reduction and Management Act, 2017)
Comprehending this need, the organization has been institutionalizing disaster response capacity building through various means. Today the army has the Disaster Management Directorate under the military operation branch. Under this directorate, one Disaster Management Training School and two disaster management battalions have been established. Besides other combat support units such as engineers and signal, and combat service support units such as aviation and medical are also the equal partner for disaster response. Besides, the Ranger Battalions have also been developed as disaster friendly units.

In the part of competency, the personnel of specialized units are indeed competent and proficient in their jobs. But the capacity of the rest of the ordinary troops is always questionable. It is because for them the disaster response training is not mandatory or carrier friendly. All the trainings are on ad hoc basis and optional.

Looking back to earlier disasters such as the 2019 Terai flood, 2019 Bara and Parsa Tornado, 2017 Terai flood, 2015 Gorkha earthquake, 2014 Jure landslide, and 2008 Koshi flood are some notable cases where the ordinary troops of Nepali Army were excessively engaged. But 'were those engagements effective' is also a question needs thorough investigation. Such an investigation will help to identify loopholes that can be redressed accordingly.

Similarly, the construction of Gupsi Pakha village of Gorkha district and reconstruction of tornado destroyed houses of Bara and Parsa districts are the examples of the army's engagement in post-disaster reconstruction (Lal, 2019; Yadav, 2019). However 'such engagement is also the need of time' but 'how productive is it for the army' and 'how will it affect the civilian capacity' is also another question needs thoughtful discourse.

\section{The police forces - Nepal Police and Armed Police Force}

In recent years disaster response has become a prime responsibility for police forces of Nepal. Besides their primary role of law and order maintenance, the institutions have been engaged in disaster response regularly. Indeed the organizations are also actively engaging in capacity building of their personnel, especially for search and rescue operations. The establishment of the Disaster Management Division in both the police forces i.e. Nepal Police and Armed Police Force is the sign of progress.

Although the forces were involved in disaster rescue since their establishment the institutionalization of this venture began only a decade ago. The international conference of Hyogo Framework for Action (18-22 January 2005) in which Nepal was also participatory, delivered a message to the world that 'a disaster is a global agenda which a person, a community and a country can't deal with' (Zhou et.al., 2014). There needs a global effort and every component of a state should mainstream disaster management in their activities. That conference 
Local level Disaster Response in Nepal: Investigating the Government Agencies.

delivered a sense of realization at the political leadership of Nepal that the 'technical search and rescue' should be the next approach. Since then the systematic institutional development for capacity building in disaster response preceded in security forces especially in Nepal Police and Armed Police Force.

The 2015 earthquake became another eye-opener for the government of Nepal to strengthen the disaster management capacity of security forces. Amongst two police forces, the Armed Police Force has been engaging in the forefront. From engraving 'disaster management engagement' in its Act to the establishment of Disaster Management Training Center, Disaster Response Battalion, and Disaster Response Base is the notable progress the organization has achieved (Sudhir, 2013). The production of Deep Water Rescue team, CSSR teams, and inclusion of disaster management training as an incentive course for career development are other gestures of progress. Collaborating with various NGO/INGOs the organization has been conducting multiple pieces of training and exercises such as Medical First Responder, Collapsed Structure Search and Rescue, Dead Body Management, and Water Rescue for its personnel. Today around $1500 \mathrm{APF}$ personnel are well trained in disaster response. In peacetime that trained personnel are busy generating awareness in local communities. Establishment of a disaster response platoon in each battalion is another ambitious program of the organization.

Similarly, Nepal Police is also vying to institutionalize disaster management venture effectively. The new organizational structure has provisioned a disaster response unit at each provincial police headquarters with the strength of 125 personnel under the command of the inspector. And currently, the Disaster Management Division is busy producing experts to fill the vacancy of those units. Forty-five days long comprehensive disaster management training has been designed as basic training for disaster response trainees. And the training is valuable for their carrier development as well.

"Disaster management is in a rudimentary stage in Nepal Police," an expert said during an interview. "We are developing an advanced course for experts" he added. Like APF in Nepal Police, there is no specialization training. And there is no training segregated for officers and other ranks. During the interview, a senior officer agreed that the police leadership is much determined to develop disaster response capability of the organization to a newer height.

\section{Specialized troops versus ordinary troops}

One issue is quite common in all three forces that the capacity of their ordinary troops, besides disaster specialized troops, is always questionable. In all forces disaster, specialized troops are in limited strength and are kept centralized. Hence at the time of crisis, they become the second echelon of response. It is because the first echelon is those ordinary troops deployed at the local level, commencing their regular duty. In that sense, the effectiveness of the local level response mechanism is moreover dependent on the capacity of those ordinary troops instead of those specialized troops who arrive at the disaster site only if called to augment the capacity of those ordinary troops. However, investigation of the competency of those ordinary troops is much important to find out the exact disaster response capacity of the organizations.

\section{DISCUSSION}

Indeed local level disaster response capacity is always questionable in Nepal. There are a few reasons for such a consequence. At first, there lacks political will at the national level. For example in MoHA conflict management and disaster management falls under a single department. They have been observed by the same lens whereas the disciplines are completely different. Therefore it's imperative that the 'disaster management' should be segregated from the 'conflict management'. And there should be a separate office at the local level to look after the venture 24/7. Although at present CDO office holds the overall responsibility is not able to give fulltime commitment. It is because the office is already overtaxed with the plethora of innate responsibilities.

Secondly, there is a lethargic tendency amongst the district and municipality level officials to work for disaster response. They are suffering from the preconceived idea that the 'disaster response' is the CDO's and security forces' baby. They need to be oriented properly. Some sort of incentives, a strong chain of command, and strong directives from respective authority may also be helpful to bring them into the right track. Their lethargy will ultimately affect the overall cluster approach.

Missing local level capacity building initiative is another shortfall of the venture. Disaster response capacity building initiative is indeed heavily reliant on NGO/ INGOs which is counterproductive for the state. Experts claim that the state's over-reliance on NGO/INGO for capacity building initiative will erode the national capacity and turns nation a parasite (Jones, 2014). There should be a national mechanism for capacity building. Along with with that, there should a regularity of resource delegation for capacity building.

Over-reliance on security forces for response operation is another drawback. Indeed for search and rescue, Nepal Army and police forces are the indispensable tools. But for health protection, relief material management, management of temporary shelters, food and drinking water management and so on civilian departments should be accountable (see table 2). And those departments shouldn't be shy of from beholding their responsibilities. Even the engagement of Army in postdisaster reconstruction is also not appropriate. It will again undermine the responsibility of civil authority.

Indeed this paper has identified that the local level disaster response is not approving in Nepal. But there is still needed to gauge the actual fault line. For that further research is needed precisely on the competency of local-level response components i.e. civil administrative officials, elected 
representatives, and security forces. While the Nepal Army is the notable stakeholder of response mechanism study of other armies' competency in disaster response may also help to bring the organization's competency at the right track.

\section{CONCLUSION}

Disaster response precisely is a local body's responsibility. The parts and parcels of local response mechanism should be competent enough in the venture. It is true that if we spent a dollar today in preparedness tomorrow we will save hundreds of dollar from spending in response. And the capacity building of local bodies is the field where we should invest today.

Indeed there is still missing required gravity at the top level to make this venture effective. Heavy reliance on NGO/INGO for capacity building is one of the deadliest fault lines that the state has neglected till date. The state should have to have own facility for capacity building. Similarly, over-reliance on security force is another drawback of the venture that ultimately aids to make civil authority lethargic. Such tendency ultimately leads to jeopardizing the cluster approach. If today due consideration is given to fill these gaps then certainly tomorrow effective local level disaster response mechanism will be established that will ultimately help to enhance the social and economic conditions of the societies of Nepal.

\section{REFERENCES}

Dawadi, B.K., 2019. Losses from calamity up to $74 \%$ in 2018. My Republica 9 January 2019.

Disaster Risk Reduction and Management Act. 2017. Part 8, Article 18. pp. 24-26.

IASC. 2006. Guidance Note on Using the Cluster Approach to Strengthen Humanitarian Response.

Kapucu, N., and Wart, M. V., 2006. The emerging role of the public sector in managing extreme events: lesson learned. Administration and Society, v.38. pp. 279-308.

Khanal, N.R. and Gurung, D. R., 2014. ICIMOD Rapid Field Investigation: Jure Landslide Dam Site Jure, Sindhupalchok District, Nepal. ICIMOD, v. 30. pp.1-7.

Kharel, S., 2018. Public Service Delivery of Local Government in Nepal in 2015. Research Nepal Journal of Development Studies, v. 1(1), pp. 83-93.

Lee, A.C.K., 2016. Barriers to evidence-based disaster management in Nepal: a qualitative Research. Public Health XXX. pp.1-8.

MacManus, S.A., and Curuson, K., 2006. Code Red: Florida City and County Officials rate threat information sources and the homeland security advisory system. State and Local Government Review, v. 38. pp. 12-22.
Lee, A.C.K., 2016. Barriers to evidence-based disaster management in Nepal: a qualitative Research. Public Health XXX. pp.1-8.

MacManus, S.A., and Curuson, K., 2006. Code Red: Florida City and County Officials rate threat information sources and the homeland security advisory system. State and Local Government Review, v. 38. pp. 12-22.

Malla, S. B., Dahal, R. K., and Hasegawa, S.,t 2019. Local Level Disaster Response Competency in Nepal: Recent (31st March, 2019) Tornado as a Case Study. First Himalayan Engineering Geological Congress (HEGC-I).

Manandhar, M. D., Varughese, G., and Howitt, A. M., 2017. Disaster Preparedness and Response during Political Transition in Nepal: Assessing Civil and Military Roles in the Aftermath of the 2015 Earthquakes. The Asia Foundation. pp. 5-6.

Marshall, A. R. C., and Adkin, R., 2015. Nepalese army gets image boost from quake relief work. In Reuters.

MoHA, 2013. National Disaster Response Framework (NDRF).

MoHA, 2017. Nepal Disaster Report 2017. pp.1-6.

MoHA, 2018. Nepal Disaster Report, 2017: The Road to Sendai, Kathmandu, Government of Nepal. pp. 1-12.

MoHA, 2018. National Position Paper on Disaster Risk Reduction and Management Nepal. AMCDRR 2018, Mongolia. pp.1-28.

MoHA and DPNET, 2015. Nepal Disaster Report 2015. p. 5.

Nepal, P., Khanal, N. R., and Sharma, B.P.P., 2018. Policies and Institutions for Disaster Risk Management in Nepal : A review. The Geography Journal of Nepal, v.11, pp.1-24.

Niekerk, D.V., 2007. Local Government Disaster Risk Management, Municipal Management: Serving the People. Juta and Company Ltd. p. 234.

Piper, R., 2013. A perfect storm of earthquake and poor governance could cripple Nepal. The guardian.

Sanderson, D. and Ramalingam, B., 2015., Nepal Earthquake Response: Lessons for Operational Agencies. ALNAP Lessons Paper. London.

Thapa, M., 2016. Out of Barracks: Civil - Military Relations in Disaster Management, A Case Study of Nepalese Army's Humanitarian Response during 2015 Earthquake in Nepal. University for Peace, San Jose.

The Constitution of Nepal, 2015. Part 28, Article 267. p.197.

The Disaster Risk Reduction and Management Act 2074. 2017. Part 7, pp 19-24.

Yadav, U., 2019. Model Houses Completed for Tornado Reconstruction. My Republica 8 May, 2019

Chettri, M.B.P., 1999. Nepal Country Report 1999. MoHA.

UNDP, 2011. Disaster-Conflict Interface Comparative 
Local level Disaster Response in Nepal: Investigating the Government Agencies.

Experiences. Bureau for Crisis Prevention and Recovery. p.11.

Zhou, L., Pereera, S., Jayawickrama, J., and Adeniyi, O., 2014. The Implementation of Hyogo Framework for Action for Disaster Resilience Education. Procedia Economics and Finance v. 18. pp. 576-583. 